\title{
Is Manual Segmentation the Real Gold Standard for Tooth Segmentation? A Preliminary in vivo Study Using Cone- beam Computed Tomography Images
}

\author{
Manuel Segmentasyon, Diş Segmentasyonu için Gerçek Altın \\ Standart mı? Konik Işınlı Bilgisayarlı Tomografi Görüntüleri \\ Üzerinde Bir On in vivo Çalışma
}

\author{
(D) Sercan Sabancı ${ }^{1}$, (D) Elif Şener ${ }^{2}$, (D) Rukiye Irmak Turhal ${ }^{2}$, (D) Barış Oğuz Gürses ${ }^{1}$, (D) Figen Gövsa ${ }^{3}$, (D) Uğur Tekin ${ }^{4}$, \\ (D) Aysun Baltacı ${ }^{1}$, (D) Hayal Boyacıoglü 5 , (D) Pelin Güneri² \\ ${ }^{1}$ Ege University Faculty of Engineering, Department of Mechanical Engineering, İzmir, Turkey \\ ${ }^{2}$ Ege University Faculty of Dentistry, Department of Oral and Maxillofacial Radiology, İzmir, Turkey \\ ${ }^{3}$ Ege University Faculty of Medicine, Department of Anatomy Digital Imaging and 3D Modelling Laboratory, İzmir, Turkey \\ ${ }^{4}$ Ege University Faculty of Dentistry, Department of Oral and Maxillofacial Surgery, İzmir, Turkey \\ ${ }^{5}$ Ege University Faculty of Science, Department of Statistics, İzmir, Turkey
}

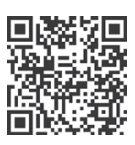

Keywords

Cone-beam computed tomography, image analysis, segmentation, impacted tooth

Anahtar Kelimeler

Konik ışınlı bilgisayarlı tomografi, görüntü analizi, bölütleme, gömülü diş

Received/Geliş Tarihi : 10.03.2021

Accepted/Kabul Tarihi : 03.05.2021

doi:10.4274/meandros.galenos.2021.14632

Address for Correspondence/Yazışma Adresi: Sercan Sabancı MD,

Ege University Faculty of Engineering, Department of Mechanical Engineering, İzmir, Turkey

Phone : +90 2323114979

E-mail : sercan.sabanci@ege.edu.tr

ORCID ID: orcid.org/0000-0002-0699-307X

(C) Meandros Medical and Dental Journal, Published by Galenos Publishing House.

This is article distributed under the terms of the

Creative Commons Attribution NonCommercial 4.0

International Licence (CC BY-NC 4.0).

\begin{abstract}
Objective: This study aimed to assess whether manual segmentation is an accurate method in tooth volume measurement and to compare the outcomes of manual, automatic, and semiautomatic segmentations on cone-beam computed tomography (CBCT) images by comparing each system with the water displacement method, which is the gold standard.

Materials and Methods: CBCT images of 10 maxillary impacted teeth were used in this preliminary in vivo study. Following the acquisition of CBCT scans, manual, automatic, and semiautomatic segmentations were completed by the same operator. After surgical removal, the volumes of all impacted teeth were measured with the water displacement method, which was used as the gold standard. The volume of each segmented image was measured in $\mathrm{mm}^{3}$ using the 3D-Doctor software. The established volumes of each segmented image were compared with those of the gold standard using the 95\% confidence interval bootstrap percentiles. Intraobserver reliability was determined using the intraclass correlation coefficient. Results: All segmentation methods revealed significantly different volume values both from the gold standard and from each other $(p=0.000)$. The semiautomatic segmentation demonstrated comparable performance with the manual method, and both systems provided comparable volumes with the gold standard than did the automatic method. Excellent intra-observer intraclass correlations were found for all protocols.

Conclusion: The actual volumes of the specimen were not obtained by manual, semiautomatic, and automatic segmentations. Semiautomatic segmentation demonstrated comparable performance to the manual method, whereas automatic segmentation yielded the poorest values. The automatic and semiautomatic segmentations may be improved by the development and utilization of novel or hybrid segmentation algorithms for a faster process and more accurate results.
\end{abstract}


Öz

Amaç: Manuel segmentasyonun (bölütleme) diş hacmini ölçmek için doğru bir yöntem olup olmadığını değerlendirmek ve konik ışınlı bilgisayarlı tomografi (CBCT) görüntülerinde manuel, otomatik ve yarı otomatik segmentasyon sonuçlarının her birini altın standart olarak kabul edilen su deplasman yöntemi ile karşılaştırmaktır.

Gereç ve Yöntemler: Bu ön in vivo çalışmada maksiller gömülü 10 dişin CBCT görüntüleri kullanılmıştır. CBCT taramalarının alınmasının ardından manuel, otomatik ve yarı otomatik segmentasyon aynı operatör tarafından tamamlanmıştır. Cerrahi olarak çıkarıldıktan sonra tüm gömülü dişlerin hacimleri altın standart olarak kullanılan su deplasman yöntemi ile ölçülmüştür. Her bölütlenmiş görüntünün hacmi, 3D-Doctor yazılımı kullanılarak $\mathrm{mm}^{3}$ cinsinden ölçülmüştür. Tüm bölütlenmiş görüntülerin belirlenen hacimleri, \%95 güven aralığı bootstrap yüzdelikleri kullanılarak altın standartlarla karşılaştırılmıştır. Gözlemci içi güvenilirlik, sınıf içi korelasyon katsayısı kullanılarak belirlenmiştir.

Bulgular: Tüm segmentasyon yöntemleri hem altın standarttan hem de birbirinden önemli ölçüde farklı hacim değerleri ortaya çıkarmıştır $(p=0,000)$. Yarı otomatik bölütleme, manuel yönteme benzer performans ortaya koymuş ve her iki sistem de otomatik yönteme göre altın standartla karşılaştırılabilir hacimler sağlamıştır. Tüm protokoller için mükemmel gözlemci içi sınıf içi korelasyonlar bulunmuştur.

Sonuç: Manuel, yarı otomatik ve otomatik segmentasyonla elde edilen sonuçlar numunelerin gerçek hacimlerinden farklı bulunmuştur. Yarı otomatik segmentasyon, manuel yönteme benzer performans sağlarken, otomatik segmentasyon altın standarda en uzak sonuçları sunmuştur. Otomatik ve yarı otomatik bölütleme, daha hızlı işlem ve daha doğru sonuçlar için yeni veya hibrit bölümleme algoritmalarının geliştirilmesi ve kullanılmasıyla iyileştirilebilir.

\section{Introduction}

During the last decades, diagnostic imaging technologies have greatly increased the knowledge of normal and diseased in many fields of medical research and clinical practice. The growing number of the imaging modalities have necessitated the use of computers to facilitate data processing and analysis (1). One of those analysis modalities is image segmentation which is defined as the partitioning of an image into non-overlapping, constituent regions that are homogeneous with respect to some characteristics such as intensity or texture (2).

Segmentation can be accomplished using manual, automatic and semi-automatic methods. The most general approach to segmentation is the manual method, where the user outlines the structures slice by slice. Manual segmentation is often used as a reference for comparison with other segmentation methods (3-5), however it is subjective, userdependent, tedious and time-consuming. On the other hand, automated segmentation is a fast, easy and operator independent method (6). Unfortunately, because of the presence of inaccuracies with respect to the delineation of the borders of the image to be segmented that often requires the operators' manual intervention and guidance, this method may not be considered appropriate especially for complex medical images (7). To overcome these problems, a lot of work has been invested in semi-automatic segmentation methods (8). In semi-automatic segmentation, the components of both the automatic and manual segmentation are included. Thus, not only the advantages but also the disadvantages of both modalities are transferred, as well. This matter has raised concerns about the accuracy and utility of semi-automatic segmentation $(3,4,9)$.

The segmentation accuracy on conventional medical computerized tomography (CT) images have been studied extensively $(7,10,11)$. Considering the fact that conventional medical CT protocols are generally associated with relatively high radiation dose levels, cone beam computerized tomography (CBCT) has gained popularity in daily dental practice for 3D imaging of the maxillofacial and dentoalveolar structures, due to its high resolution for hard tissues and relatively low radiation exposure (10). Accurate segmentation of regions of interest by using computer algorithms is becoming increasingly important in assisting dentomaxillofacial diagnosis, treatment planning and outcome evaluation $(6,12-14)$. On CBCT images, segmentation has been utilized to assess the tongue volume which is an important contributor to the etiology of dental malocclusions, dentofacial deformities (15) and sleep apnea disorders (16). Segmentation becomes even more imperative to avoid post-operative complications prior to dental implant placement, third molar surgical removal and other craniofacial or orthognathic surgical operations, and also to accurately diagnose numerous vascular 
and neurogenic pathologies associated with the mandibular nerve $(17,18)$. Segmentation is also exploited for establishment of morphological changes within the temporomandibular joint to provide data about functional/pathological alterations of the mandibular complex $(19,20)$. Additionally, for detection of the volume of neoplastic or nonneoplastic osteolytic lesions of the jaws, automatic segmentation on CBCT images can provide promising results $(17,21)$. In orthodontics, development of the external root resorption can be observed by calculation of the volume of the tooth (4). Similarly, segmentation has been employed in the evaluation of lesion healing after endodontic surgery (13), in 3D analyses of root canal anatomy $(6,22,23)$, and even in age estimation in forensic dentistry (24). However, СBCT images have relatively poor quality due to limited radiation exposure and low signal to noise ratio $(25,26)$, which makes the segmentation more challenging than that in $\mathrm{CT}$, especially for the tooth structures. Higher image noise, lower image contrast between the tooth root and the alveolar bone and close proximity of adjacent tooth structures are the reasons that complicate the tooth segmentation on CBCT images (27).

There are studies in dental literature evaluating the accuracy of segmentation of tooth structures by using different $\mathrm{CBCT}$ machines and/or 3D printing technologies $(4,5,7,26,28-30)$. However; in most of those investigations, manual segmentation method $(5,7,29)$ or micro-CT $(4,30)$ have been employed as the gold standard.

To the authors' knowledge, there is no published data assessing the accuracy of the manual segmentation bycomparing the volume measurements of segmented and the actual anatomical tooth using in vivo $\mathrm{CBCT}$ images. Likewise, there is no research comparing the accuracy of manual, semi-automatic and automatic tooth segmentation by using the real anatomical tooth measurements as the gold standard. Additionally, the tooth anatomical structure is unique since it has different contrast values at the crown and root, and thus, it is usually considered as a major constraint in such study designs (3). Due to this complexity, only few studies have used multi rooted teeth for age estimation in dental forensics $(31,32)$.

In the literature, different segmentation methods are evaluated both in ex vivo or in vivo studies.
The anatomic location of the object that would be segmented is a very important parameter $(3,33)$ since the outlines of that particular object has to be clearly delineated both manually and automatically. However, easily outlined in vivo hard tissues such as temporomandibular joint and impacted third molars have been utilized in many papers $(19,34,35)$. Considering that the preferred segmentation method has to be as accurate as possible even in very complicated in vivo cases and the most complex tooth-root anatomical structure has been observed in the cases of impacted teeth (36), the accuracy of different segmentation needs to be assessed on impacted teeth.

Therefore, the aim of this study was to assess whether manual segmentation is an accurate method of volume measurement in impacted maxillary teeth by comparing the outcomes of manual, automatic and semi-automatic segmentation methods on CBCT images with water displacement method, which is accepted as the gold standard.

\section{Materials and Methods}

\section{Study Sample}

A total of 10 individuals referred to the Department of Oral and Maxillofacial Radiology, Faculty of Dentistry, Ege University for CBCT evaluation in order to assess the positions and relationships of impacted maxillary teeth with adjacent roots or other anatomic structures before surgery were included in the present pilot study. The study protocol was approved by the Ethics Committee of the Medical Faculty of Ege University (approval \#16-12/11, 01.03.2017) and was conducted according to the Declaration of Helsinki on experimentation involving humans.

\section{Radiographic Technique}

CBCT examinations were performed using the Kodak 9000 3D (Kodak Carestream Health, Trophy, France) system and the imaging parameters were 10 $\mathrm{mA}$ and $70 \mathrm{kVp}$ with $2.5 \mathrm{~mm}$ Al equivalent filtration. CBCT acquisition of each patient was completed after a single $360^{\circ}$ rotation with $10.8 \mathrm{~s}$ scan time, and a volume with a spatial resolution of $76 \mu \mathrm{m}$ (isotropic voxel) was reconstructed. All images were taken by the same operator and the DICOM files of the CBCT images were saved to a portable hard disk. 


\section{Surgical Procedure}

Before surgery, patients were informed about possible complications of removal of the impacted tooth and their written informed consents were obtained. All impacted teeth were extracted by the same surgeon using standard surgery protocol for impacted tooth removal under local anaesthesia ( $2 \%$ articaine and epinephrine 1:1000.000), with similar surgical instruments.

\section{Segmentation}

CBCT images of 10 impacted teeth were used in this preliminary in vivo study. Manual, semi-automatic and automatic segmentation and reconstruction procedures are shown in Figure 1. Semiautomatic and automatic segmentation of DICOM images were performed by using the thresholding method. Firstly, DICOM images were imported in 3D-doctor (Able Software Corp, MA, USA) and the voxel heights of the images were calibrated. Then the region of interest

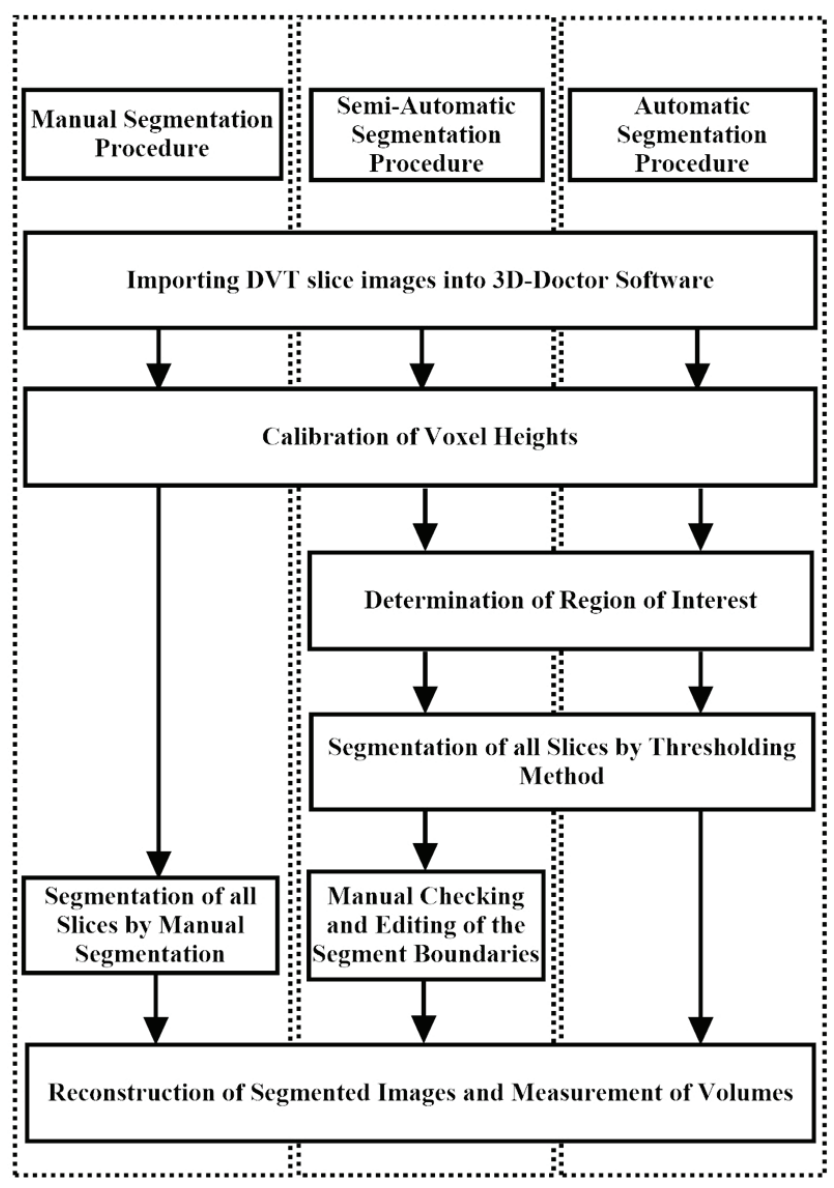

Figure 1. Protocol of segmentation and reconstruction procedures
(ROI) was determined while it was ensured that the tooth which to be segmented was left in the ROI in all sections. The images were segmented with the determined threshold, reconstructed in 3D-doctor and their volumes were measured. In semi-automatic segmentation, this procedure was performed by manual editing of the images before reconstruction (Figure 1).

\section{Thresholding Method}

Thresholding method is one of the basic and most important methods in the processing of medical images. This method is essentially a segmentation method for separating objects from the background by using a threshold T-value that is determined in the histogram showing the gray level distributions of the image, and the pixels in the image are compared to that threshold.

For a given image $f(i, j)$ for any $(i, j)$ pixel in the image, threshold image $g(i, j)(37)$;

$$
g(i, j)=\left\{\begin{array}{l}
1, \text { iff }(i, j)>T \\
0, \text { iff }(i, j) \leq T
\end{array}\right\}
$$

In order to establish the optimum threshold value in automatic and semi-automatic segmentation of teeth, bisection search which is a root-finding method that can be used for one dimensional global optimization problems (38) deemed appropriate. The determination of the optimum threshold can be formulated as a minimization problem of histogram curve of the image and can be estimated by finding the local minima between the peaks points corresponding to the teeth and the background in the histogram. In this method, the optimum threshold value must be the largest threshold value that prevents over segmentation while maintaining the shape and size of the segmented teeth in the previous slice (39). On each slice of CBCT images of 10 teeth, manual (Figure $2 a$ ), semi-automatic (Figure $2 b$ ) and automatic (Figure 2c) segmentation were performed.

The manual and semi-automatic segmentation were repeated three times by the same operator. In each segmentation, the time required from the start to the end of segmentation was also recorded.

\section{Reconstruction of Segmented Images and Volume Measurements}

After completion of manual, semi-automatic and automatic segmentation for 10 teeth, segmented 
section images were reconstructed in 3D-doctor software (Figure 3 ) to create $3 \mathrm{D}$ models and the radiographic volumes of the teeth were measured from these models.

\section{Physical Volume Measurements of the Teeth (Gold Standard)}

The physical volumes of the operated teeth were measured with the Precisa XB 220A analytical balance using the water displacement method (Archimedes principle). A $10 \mathrm{~mL}$ cylinder with 0.1 $\mathrm{mL}$ gradations was filled with room temperature water up to the $9 \mathrm{~mL}$ mark and the tooth was dipped completely into the cylinder. After immersion, the water level was recorded. Using the pre and post immersion readings, the volume of each tooth was measured. The procedure was repeated three times to reduce measurement errors and the mean of three measurements was used as the physical volume of the tooth, that is the gold standard for that particular tooth.

\section{Statistical Analysis}

The comparisons between the gold standards and the radiographic volumes obtained with manual, semi-automatic and automatic segmentation were performed using repeated analyses of variance. In order to assess the significance of the differences in post hoc comparisons of ANOVA analysis, bootstrapping sampling method was used. With the intention of deriving less biased standard errors, a total of 1.000 bootstraps were created from the data set. The bias, standard error and the upper and lower levels of $95 \%$ confidence interval were established. In order to assess the intraobserver agreement, the measurements were performed twice with an interval of three months and the reliability of the observer was assessed with intraclass correlation coefficient (ICC).
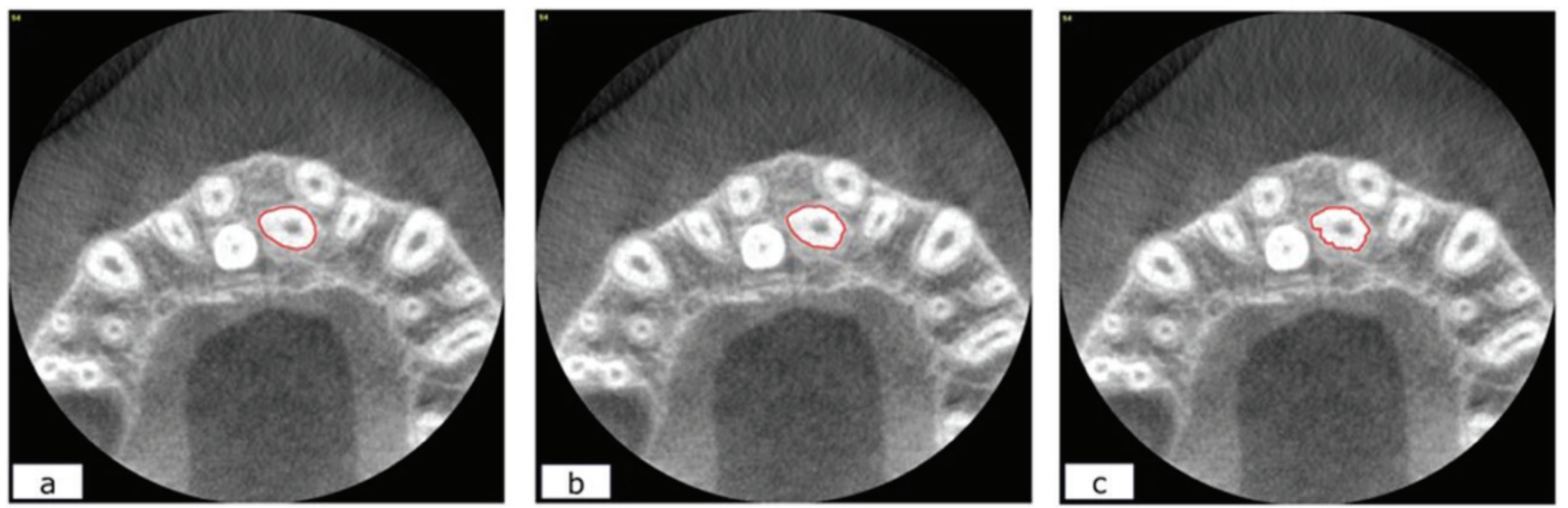

Figure 2. Images specimens of a) manuel, b) semi-automatic and c) automatic segmented image of same slices
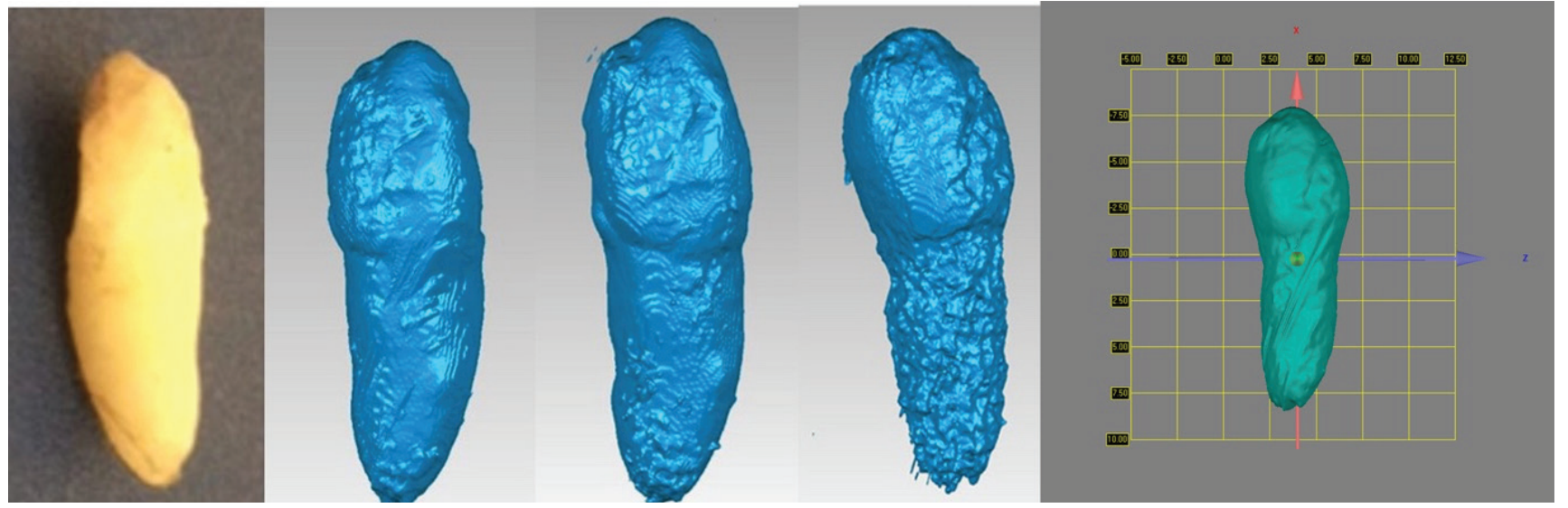

Figure 3. Reconstructed 3D geometry specimen 
The data were analyzed with SPSS version 15.0 (SPSS, Chicago, Illinois, USA). In all tests, p was set as 0.05 .

\section{Results}

The mean radiographic volume measurements for manual, semi-automatic and automatic segmentation and the gold standards are presented in Table 1. ANOVA analysis revealed that the differences between the gold standard and the mean volume measurements obtained with manual, semi-automatic and automatic segmentation were statistically significant in all samples $(p=0.000)$.

The segmentation method which presented the closest values to the gold standard measurements was revealed with the post hoc bootstrap analysis (Table 2). Among 10 samples, semiautomatic method values were similar to the gold standard in 5 samples (sample \#1,5,6,7 and 10), whereas manual method revealed lower differences in samples 2,3,4,8 and 9 .

In the present study, the ICC was 0.999 (95\% confidence interval ranged between 0.996 and 1.000) and the observer's level of reliability was considered as "excellent" $(p<0.05) \quad($ ICC $<0.5$ : poor reliability, ICC=0.5-0.75: moderate reliability, ICC=0.75-0.9: good reliability, ICC $>0.90$ : excellent reliability).

Regarding the time required for segmentation process, the automatic segmentation lasted less than average 1 second per slice, while the manual segmentation took approximately 22 seconds per slice and the semi-automatic segmentation lasted on average 10 seconds per slice. The differences were statistically significant $(p=0.000)$.

\section{Discussion}

Segmentation using a global threshold based method on image intensity values is common in medical modeling (33,40-42). However, it has limitations in dental modeling both because of the variability of the density of the structures within the maxillofacial region and the technical capabilities of the devices and algorithms used in dental imaging $(13,33)$. The density of tooth is heterogeneous from crown to apexand this natural feature leads to less clear difference between the root and the alveolar bone as the contrast between the root and bone decreases. This, consequently, impedes segmentation of the tooth from alveolar bone (3). In the present study, the segmentation was performed on impacted maxillary teeth, which makes this procedure especially arduous because of the close proximity of the impacted teeth to the roots and apices of the adjacent teeth and other anatomical structures. Besides, due to the strong noise, low contrast of tooth roots and sockets, and intensity inhomogeneity in CBCT images, accurate segmentation of tooth regions suffers from great challenges. Similar considerations were presented for automatic segmentation of mandibular condyle using CBCT images (19). Low bone density of the condylar bone but high density of the petrous temporal bone, presence of adjacent anatomical structures, the conical shape of the CBCT beam, and low contrast resolution of the CBCT data have been stressed as the confounding factors (19). Thus, segmentation of tooth from CBCT images to reveal the root anatomy and supporting bone requires a more comprehensive model compared with medical CT images. Recently,

\begin{tabular}{|l|l|l|l|l|}
\hline \multicolumn{4}{|l}{ Table 1. Volumes in $\mathrm{mm}^{3}$ of 3D geometries of reconstructed images and physical volume measurements of each tooth } \\
\hline Sample \# & Manual & Semi-automatic & Automatic & Gold standard \\
\hline 1 & 185.79 & 197.09 & 173.55 & 207.45 \\
\hline 2 & 184.10 & 182.59 & 181.61 & 195.06 \\
\hline 3 & 391.76 & 405.53 & 414.13 & 396.79 \\
\hline 4 & 244.66 & 236.17 & 240.43 & 264.68 \\
\hline 5 & 232.43 & 240.16 & 236.91 & 253.36 \\
\hline 6 & 163.82 & 163.24 & 169.34 & 162.22 \\
\hline 7 & 325.19 & 326.99 & 321.94 & 347.01 \\
\hline 8 & 304.46 & 289.17 & 283.55 & 343.63 \\
\hline 9 & 151.86 & 147.14 & 119.86 & 198.49 \\
\hline 10 & 308.68 & 312.74 & 308.4 & 366.48 \\
\hline
\end{tabular}




\begin{tabular}{|c|c|c|c|c|c|c|}
\hline \multirow[b]{3}{*}{ Sample } & \multirow[b]{3}{*}{ Method } & \multirow[b]{3}{*}{ Mean difference* } & \multicolumn{4}{|c|}{ Bootstrap multiple comparisons } \\
\hline & & & \multirow[b]{2}{*}{ Bias } & \multirow[b]{2}{*}{ Standard error } & \multicolumn{2}{|c|}{ BCa $95 \%$ confidence interval } \\
\hline & & & & & Lower & Upper \\
\hline \multirow{3}{*}{1} & Manual & 21.65 & -0.05 & 1.99 & 16.88 & 24.56 \\
\hline & Semi-auto & 10.36 & \begin{tabular}{|l|}
-0.04 \\
\end{tabular} & 0.45 & 9.48 & 11.24 \\
\hline & Auto & 33.9 & -0.03 & 0.37 & 33.24 & 34.8 \\
\hline \multirow{3}{*}{2} & Manual & 10.95 & 0.05 & 0.41 & 10.01 & 11.68 \\
\hline & Semi-auto & 12.45 & 0.01 & 0.2 & 12.07 & 12.83 \\
\hline & Auto & 13.45 & 0.02 & 0.17 & 13.01 & 13.71 \\
\hline \multirow{3}{*}{3} & Manual & 5.02 & $\mid-0.12$ & 1.14 & 2.98 & 7.36 \\
\hline & Semi-auto & \begin{tabular}{|l|}
-8.73 \\
\end{tabular} & \begin{tabular}{|l|}
-0.11 \\
\end{tabular} & 0.98 & -10.21 & -6.59 \\
\hline & Auto & -17.33 & 0.14 & 0.95 & -18.51 & -14.96 \\
\hline \multirow{3}{*}{4} & Manual & 20.02 & 0.09 & 1.76 & 15.99 & 23.12 \\
\hline & Semi-auto & 28.51 & \begin{tabular}{|l|}
0.01 \\
\end{tabular} & 1.72 & 25.06 & 31.59 \\
\hline & Auto & 24.25 & $\mid-0.01$ & 1.34 & 21.21 & 26.17 \\
\hline \multirow{3}{*}{5} & Manual & 20.93 & -0.03 & 1.04 & 18.51 & 22.4 \\
\hline & Semi-auto & 13.2 & -0.02 & 1.01 & 10.83 & 14.44 \\
\hline & Auto & 16.45 & $\mid-0.02$ & 1.01 & 14.11 & 17.62 \\
\hline \multirow{3}{*}{6} & Manual & -1.6 & -0.05 & 0.66 & -2.62 & -0.15 \\
\hline & Semi-auto & $\mid-1.02$ & -0.08 & 0.64 & -1.87 & 0.49 \\
\hline & Auto & $\mid-7.12$ & $\mid-0.07$ & 0.63 & -7.91 & -5.55 \\
\hline \multirow{3}{*}{7} & Manual & 21.81 & 0.1 & 2.73 & 16.36 & 27.19 \\
\hline & Semi-auto & 20.01 & 0.09 & 2.71 & 14.57 & 25.29 \\
\hline & Auto & 25.05 & 0.08 & 2.7 & 19.67 & 30.31 \\
\hline \multirow{3}{*}{8} & Manual & 39.17 & -0.19 & 3.98 & 31.3 & 47.3 \\
\hline & Semi-auto & 54.46 & -0.12 & 3.89 & 47.01 & 62.32 \\
\hline & Auto & 60.08 & $\mid-0.11$ & 3.88 & 52.65 & 67.91 \\
\hline \multirow{3}{*}{9} & Manual & 46.62 & 0.01 & 2.07 & 42.03 & 49.98 \\
\hline & Semi-auto & 51.34 & 0.01 & 2.06 & 46.79 & 54.64 \\
\hline & Auto & 78.62 & 0.07 & 2.06 & 74.08 & 81.9 \\
\hline \multirow{3}{*}{10} & Manual & 57.79 & \begin{tabular}{|l|}
-0.02 \\
\end{tabular} & 1.84 & 54.38 & 61.24 \\
\hline & Semi-auto & 53.74 & 0.13 & 1.06 & 51.56 & 55.37 \\
\hline & Auto & 58.07 & 0.12 & 1.02 & 55.53 & 59.39 \\
\hline
\end{tabular}

several segmentation methods and processing algorithms are being actively developed to overcome these problems. Some have proposed to segment the crown and the root separately with two level set approaches $(3,4,12,28)$ and others have proposed improved hybrid active contour model to accurately distinguish tooth structure from its surroundings $(9,39)$. However, in most of these studies, segmentation accuracy was tested by methods that could only be implemented under in vitro conditions $(9,12,28,39)$. Performing the experiments under in vitro settings does not accurately mimic clinical environments, and therefore, they do not represent the real efficacy and accuracy of segmentation methods. Only a few studies have tried to determine the accuracy of volumetric analysis of teeth on in vivo images using $\mathrm{CBCT}(3,4,33)$. In 2010, Liu et al. (3) evaluated the validity of in vivo tooth volume determinations using two different 
CBCT machines with different exposure settings. The authors used water displacement method as the gold standard to assess and compare the CBCT and actual volume values of 24 premolar teeth. They found that there was a significant difference between the physical volume measurements of the extracted teeth and CBCT measurements $(p<0.05)$. However, the accuracy of only one segmentation method (semi-automated with manual intervention) was evaluated in that study. Besides, using two observers and two different CBCT machines on segmentation procedure showed statistically different tendencies with the CBCT volumetric measurements. In another study by Wang et al. (4), 27 premolars were scanned with $\mathrm{CBCT}$ before extraction and with micro-CT after extraction (micro-CT was used as a reference system for comparison). The authors utilized an individual segmentation threshold and revealed comparable results with CBCT and micro-CT. Recently, the accuracy of tooth segmentation was evaluated using four different windowing protocols for manual method by comparing the volumes obtained from CBCT segmentations. Laser scanning method was employed as the gold standard and the results revealed that only one windowing protocol showed significantly closer volumes to the gold standard (33). Most of these studies evaluating the accuracy of different segmentation procedures have used manual segmentation as the gold standard $(5,7,29)$. However, to the authors knowledge, there is no study in the literature that used in vivo $\mathrm{CBCT}$ images to evaluate the accuracy of manual segmentation by using the physical tooth volume as the gold standard and to compare three different tooth segmentation procedures. The present study revealed that even though manual segmentation method requires meticulous delineation of the structures which are to be segmented, it provides significantly different volumetric values from the actual volume of the specimen and cannot be considered as the gold standard. So, in clinical applications of segmentation, especially prior to surgical operations in complicated cases, the reliability of the manual segmentation shall be questioned.

Image segmentation-based volume assessment is presented as an accurate method that provides comparative analysis of jaw lesions (17). However, the results of the present study showed that mean radiographic volume measurements for manual, semi-automatic and automatic segmentation were significantly lower than the gold standard values. It's stated that using a uniform threshold for tooth segmentation could result in data loss because of the variable density values of teeth and surrounding tissues among different individuals (3). Additionally, the threshold level needed to be adjusted since the anatomy and density of a tooth is heterogeneous from the crown to the apex. A tooth crown is easier to segment due to its mineralized enamel which presents a distinct contrast with the adjacent air. On the contrary, there is a less clear difference between the root tissue and the surrounding alveolar bone. These anatomical characteristics cause heterogeneity of the tissue density which results with significantly different densities from crown to apex on the image, leading to more complicated segmentation process (12). Our lower mean radiographic volume measurements for manual, semi-automatic and automatic segmentation than the gold standard values may be the outcome of this above-mentioned data loss due to the uniform threshold level. Due to these findings, application of different threshold values to the crown and root of the tooth rather than using a single and standard threshold may be suggested for automatic and semiautomatic segmentation.

The other parameters that could influence the qualitative and quantitative aspects of segmentation procedure were the maxillary or mandibular location of the tooth (3), and the position of the tooth within the alveolar arch (33). Previous studies revealed that mandibles show a better CBCT image quality than maxillae since it has greater contrast between the dental alveolus and the surrounding cortex (43). Most of tooth segmentation studies concluded that segmentation procedure becomes more difficult when the roots are closer to the cortical bone or in close contact with adjacent teeth $(3,33)$. In the present study, the impacted teeth were not at their original positions within the dental arch and were located mostly close to the adjacent teeth and cortical bone. Additionally, all of our cases were the maxillary impacted teeth, and since maxillae have poorer image quality, this was probably the most prominent cause of the challenges in delineation of anatomic structures. These parameters may be other possible reasons of lower radiographic volume measurement values as 
compared with the gold standard. Considering the literature, the cases utilized in the present were the most complicated and challenging ones for in vivo segmentation procedure.

Despite potential indications for dental segmentation, enrollment of the observers is still considered as the major pitfall of the technique. Using more than one observer has resulted with varying radiographic volume measurements obtained with CBCT images and gold standard, and statistically significant difference between the observers was attributed as the cause of this outcome (3). Both for manual and semi-automatic segmentation procedures, human eye is required to delineate the structures of interest from the adjacent areas (29) and this may be the origin of subjectivity of the observers. Additionally, the experience and the knowledge of the observer regarding the dental anatomy contribute to the overall performance and consequently, the accuracy of the segmentation process (33). Another problem is the time spent during segmentation procedures. Elongated procedure time especially during the manual segmentation process may cause tiredness of the observers, and influence the reliability of the observer/method $(7,44)$. This was also observed in the present study, and manual segmentation required more time than the semiautomatic and automatic segmentation procedures.

A major limitation of the present pilot study is the small number of sample size. The integrity of the tooth material was vital to measure the actual tooth volume, which was the gold standard. Unfortunately, it was difficult to remove the impacted maxillary teeth as intact structures during surgical operations, and this was the main reason of low sample size. At this point, in order to help to diminish the time spent and subjective aspects of the segmentation procedure, further studies are required with a larger sample size to investigate the development and performance of new or hybrid algorithms on semi-automatic segmentation.

\section{Conclusion}

For the first time in the literature, the present study has evaluated the accuracy of manual, semiautomatic and automatic segmentation methods by comparing the radiographic volumetric values of the teeth obtained on in vivo CBCT images and the physical teeth volumes. Even though in vivo conditions complicated the segmentation of the teeth, we observed that radiographic volume values that were acquired with manual segmentation were significantly different than the physical volumes of the teeth. Our results revealed that automatic segmentation yielded the poorest values whereas semi-automatic segmentation was as accurate as manual segmentation procedure. The automatic and semi-automatic segmentation methods may be improved by development and utilization of novel or hybrid segmentation algorithms for more accurate results, that is imperative especially for treatment planning of surgical operations which may possess significant postoperative complications.

\section{Acknowledgement}

This study was funded by Ege University with Scientific Research project number: 17-Diş-015.

\section{Ethics}

Ethics Committee Approval: The study protocol was approved by the Ethics Committee of the Medical Faculty of Ege University (approval \#16-12/11, 01.03.2017) and was conducted according to the Declaration of Helsinki on experimentation involving humans.

Informed Consent: Informed consent was obtained.

Peer-review: Externally peer-reviewed.

\section{Authorship Contributions}

Concept: P.G., E.Ş., S.S., F.G., Design: P.G., E.Ş., S.S., Supervision: P.G., F.G., E.Ş., Fundings: B.O.G., P.G., E.Ş., Materials: U.T., Data Collection or Processing: R.I.T., Analysis or Interpretation: S.S., H.B., Literature Search: A.B., E.Ş., Writing: E.Ş., P.G., S.S., Critical Review: P.G., E.Ş., A.B., S.S., B.O.G.

Conflict of Interest: No conflict of interest was declared by the authors.

Financial Disclosure: The authors declared that this study received no financial support.

\section{References}

1. Pham DL, Xu C, Prince JL. Current methods in medical image segmentation. Annu Rev Biomed Eng 2000; 2: 315-37.

2. Pal NR, Pal SK. A review on image segmentation techniques. Pattern Recognit 1993; 26: 1277-94. 
3. Liu Y, Olszewski R, Alexandroni ES, Enciso R, Xu T, Mah JK. The validity of in vivo tooth volume determinations from cone-beam computed tomography. Angle Orthod 2010; 80: 160-6.

4. Wang Y, He S, Yu L, Li J, Chen S. Accuracy of volumetric measurement of teeth in vivo based on cone beam computer tomography. Orthod Craniofac Res 2011; 14: 206-12.

5. Forst D, Nijjar S, Flores-Mir C, Carey J, Secanell M, Lagravere M. Comparison of in vivo 3D cone-beam computed tomography tooth volume measurement protocols. Prog Orthod 2014; 15: 69.

6. Michetti J, Georgelin-Gurgel M, Mallet JP, Diemer F, Boulanouar $\mathrm{K}$. Influence of CBCT parameters on the output of an automatic edge-detection-based endodontic segmentation. Dentomaxillofac Radiol 2015; 44: 20140413.

7. Rana M, Modrow D, Keuchel J, Chui C, Rana M, Wagner M, et al. Development and evaluation of an automatic tumor segmentation tool: a comparison between automatic, semiautomatic and manual segmentation of mandibular odontogenic cysts and tumors. J Craniomaxillofac Surg 2015; 43: 355-9.

8. Schenk A, Prause G, Peitgen HO. Efficient semiautomatic segmentation of 3D objects in medical images. In: Lecture Notes in Computer Science (including subseries Lecture Notes in Artificial Intelligence and Lecture Notes in Bioinformatics) 2000; 1-10.

9. Wang Y, Liu S, Wang G, Liu Y. Accurate tooth segmentation with improved hybrid active contour model. Phys Med Biol 2018; 64: 015012.

10. Loubele M, Maes F, Schutyser F, Marchal G, Jacobs R, Suetens $P$. Assessment of bone segmentation quality of cone-beam CT versus multislice spiral CT: a pilot study. Oral Surg Oral Med Oral Pathol Oral Radiol Endod 2006; 102: 225-34.

11. Xia Z, Gan Y, Chang L, Xiong J, Zhao Q. Individual tooth segmentation from CT images scanned with contacts of maxillary and mandible teeth. Comput Methods Programs Biomed 2017; 138: 1-12.

12. Ji DX, Ong SH, Foong KW. A level-set based approach for anterior teeth segmentation in cone beam computed tomography images. Comput Biol Med 2014; 50: 116-28.

13. Schloss T, Sonntag D, Kohli MR, Setzer FC. A Comparison of 2and 3-dimensional Healing Assessment after Endodontic Surgery Using Cone-beam Computed Tomographic Volumes or Periapical Radiographs. J Endod 2017; 43: 1072-9.

14. Queiroz PM, Rovaris K, Santaella GM, Haiter-Neto F, Freitas DQ. Comparison of automatic and visual methods used for image segmentation in Endodontics: a microCT study. J Appl Oral Sci 2017; 25: 674-9.

15. Uysal T, Yagci A, Ucar FI, Veli I, Ozer T. Cone-beam computed tomography evaluation of relationship between tongue volume and lower incisor irregularity. Eur J Orthod 2013; 35: 555-62.

16. Rana SS, Kharbanda OP, Agarwal B. Influence of tongue volume, oral cavity volume and their ratio on upper airway: A cone beam computed tomography study. J Oral Biol Craniofac Res 2020; 10 : 110-7.

17. Kauke M, Safi AF, Grandoch A, Nickenig HJ, Zöller J, Kreppel M. Image segmentation-based volume approximation-volume as a factor in the clinical management of osteolytic jaw lesions. Dentomaxillofac Radiol 2019; 48: 20180113.

18. Kwak GH, Kwak EJ, Song JM, Park HR, Jung $\mathrm{YH}$, Cho BH, et al. Automatic mandibular canal detection using a deep convolutional neural network. Sci Rep 2020; 10: 5711.

19. Verhelst PJ, Shaheen E, de Faria Vasconcelos K, Van der Cruyssen F, Shujaat S, Coudyzer W, et al. Validation of a 3D CBCT-based protocol for the follow-up of mandibular condyle remodeling. Dentomaxillofac Radiol 2020; 49: 20190364.

20. Altan Şallı G, Öztürkmen Z. Semi-automated three-dimensional volumetric evaluation of mandibular condyles. Oral Radiol 2021; 37: 66-73.

21. Abdolali F, Zoroofi RA, Otake Y, Sato Y. Automatic segmentation of maxillofacial cysts in cone beam CT images. Comput Biol Med 2016; 72: 108-19.

22. Anssari Moin D, Hassan B, Wismeijer D. A novel approach for custom three-dimensional printing of a zirconia root analogue implant by digital light processing. Clin Oral Implants Res 2017; 28: 668-70.

23. Verweij JP, Jongkees FA, Anssari Moin D, Wismeijer D, van Merkesteyn JPR. Autotransplantation of teeth using computeraided rapid prototyping of a three-dimensional replica of the donor tooth: a systematic literature review. Int J Oral Maxillofac Surg 2017; 46: 1466-74.

24. Vandevoort FM, Bergmans L, Van Cleynenbreugel J, Bielen DJ, Lambrechts $P$, Wevers $M$, et al. Age calculation using X-ray microfocus computed tomographical scanning of teeth: a pilot study. J Forensic Sci 2004; 49: 787-90.

25. Shahbazian M, Jacobs R, Wyatt J, Denys D, Lambrichts I, Vinckier F, et al. Validation of the cone beam computed tomography-based stereolithographic surgical guide aiding autotransplantation of teeth: clinical case-control study. Oral Surg Oral Med Oral Pathol Oral Radiol 2013; 115: 667-75.

26. Shaheen E, Khalil W, Ezeldeen M, Van de Casteele E, Sun Y, Politis C, et al. Accuracy of segmentation of tooth structures using 3 different CBCT machines. Oral Surg Oral Med Oral Pathol Oral Radiol 2017; 123: 123-8.

27. Hiew LT, Ong SH, Foong KWC. Tooth segmentation from conebeam CT using graph cut. In: APSIPA ASC 2010 - Asia-Pacific Signal and Information Processing Association Annual Summit and Conference 2010; 272-5.

28. Khalil W, EzEldeen M, Van De Casteele E, Shaheen E, Sun $Y$, Shahbazian $M$, et al. Validation of cone beam computed tomography-based tooth printing using different threedimensional printing technologies. Oral Surg Oral Med Oral Pathol Oral Radiol 2016; 121: 307-15.

29. Vallaeys K, Kacem A, Legoux H, Le Tenier M, Hamitouche C, Arbab-Chirani R. 3D dento-maxillary osteolytic lesion and active contour segmentation pilot study in CBCT: semi-automatic vs manual methods. Dentomaxillofac Radiol 2015; 44: 20150079.

30. Wang Y, He S, Guo Y, Wang S, Chen S. Accuracy of volumetric measurement of simulated root resorption lacunas based on cone beam computed tomography. Orthod Craniofac Res 2013; 16: $169-76$. 
31. Aboshi H, Takahashi T, Komuro T. Age estimation using microfocus $\mathrm{X}$-ray computed tomography of lower premolars. Forensic Sci Int 2010; 200: 35-40.

32. Ge ZP, Yang P, Li G, Zhang JZ, Ma XC. Age estimation based on pulp cavity/chamber volume of 13 types of tooth from cone beam computed tomography images. Int J Legal Med 2016; 130 : 1159-67.

33. Rastegar B, Thumilaire B, Odri GA, Siciliano S, Zapała J, Mahy P, et al. Validation of a windowing protocol for accurate in vivo tooth segmentation using i-CAT cone beam computed tomography. Adv Clin Exp Med 2018; 27: 1001-8.

34. Xi T, van Loon B, Fudalej P, Bergé S, Swennen G, Maal T. Validation of a novel semi-automated method for three-dimensional surface rendering of condyles using cone beam computed tomography data. Int J Oral Maxillofac Surg 2013; 42: 1023-9.

35. Méndez-Manjón I, Haas OL Jr, Guijarro-Martínez R, Belle de Oliveira R, Valls-Ontañón A, Hernández-Alfaro F. SemiAutomated Three-Dimensional Condylar Reconstruction. J Craniofac Surg 2019; 30: 2555-9.

36. Becker A. Orthodontic Treatment of Impacted Teeth: Third Edition. Orthodontic Treatment of Impacted Teeth: Third Edition. 2013.

37. Senthilkumaran N, Vaithegi S. Image Segmentation By Using Thresholding Techniques For Medical Images. Comput Sci Eng An Int J. 2016; 6: 1-13.
38. Encyclopedia of optimization. 2nd ed. Springer reference. New York: Springer; 2009. p. 7.

39. Kang HC, Choi C, Shin J, Lee J, Shin YG. Fast and Accurate Semiautomatic Segmentation of Individual Teeth from Dental CT Images. Comput Math Methods Med 2015; 2015: 810796.

40. Karakas AB, Govsa F, Ozer MA, Eraslan C. 3D Brain Imaging in Vascular Segmentation of Cerebral Venous Sinuses. J Digit Imaging 2019; 32: 314-21.

41. Govsa F, Ozer MA, Biceroglu H, Karakas AB, Cagli S, Eraslan C, et al. Creation of 3-Dimensional Life Size: Patient-Specific C1 Fracture Models for Screw Fixation. World Neurosurg 2018; 114: e173-81.

42. Ozturk AM, Sirinturk S, Kucuk L, Yaprak F, Govsa F, Ozer MA, et al. Multidisciplinary Assessment of Planning and Resection of Complex Bone Tumor Using Patient-Specific 3D Model. Indian J Surg Oncol 2019; 10: 115-24.

43. Gateno J, Xia J, Teichgraeber JF, Rosen A. A new technique for the creation of a computerized composite skull model. J Oral Maxillofac Surg 2003; 61: 222-7.

44. Yushkevich PA, Piven J, Hazlett HC, Smith RG, Ho S, Gee JC, et al. User-guided $3 \mathrm{D}$ active contour segmentation of anatomical structures: significantly improved efficiency and reliability. Neuroimage 2006; 31: 1116-28. 